senting the mill and shop owners who have sent their ambitious sons and successors-to-be to these institutions, realizing that the instruction there given is equally practical and far more thorough than is obtained in their own mills or shops, besides including a host of things that neither weave room nor machine shop can teach.

No man of intelligence denies that theoretical courses are of primary importance in affording mental discipline not to be derive from practical research. So in these schools, theory and practice are made to go hand in hand, on the basis that from continual and practical applications of theoretical conclusions a broader and more tangible conception of their truths may be derived.

An excellent example of the practical plane the technical school has gaine is Georgia's State School of Technology. The manufactures resulting from the work of the students, where the product is not for the use of the school itself, are sold, just as the output of any other producing plant is dispose of. The studen understands from the first that his work is practical, and he is require to exercise the same energy and skill he would devote to his task if his daily bread depended on the result of his efforts.

The growth of the textile industry in the Southern States has resulte in an increasing demand for executive mill men, superintendents, and others, who com bine with the practical training the mills give that knowledge which runs to cause and effect, what may be calle the higher education in textile matters, including a sound foundation in engineering subjects.

So the technical-school course includes, besides the usual subjects of the textile school-such as carding, spinning, weaving, designing, and dyeing-extensive courses in chemistry, physics, mechanics, drawing, strength of materials, steam engine, electrical work, mill construction, and shop work.

The course not only covers the theoretical sides of the different subjects, but is extremely practical. For example, with a few exceptions where very fine or fancy yarns are required, students make and dye all the yarn use in the weave room. This yarn and the cloth product are yept up to the standard as are ously as in the mills of the high est class, because the product is place on the market and sold. The subject of fabric structure is given especial attention in its relation to the different combinations of textures and weaves, the classification of iabrics, the "balance of cloth" necessary to give the maximum of wearing qualities, and best general appearance, influence of twist in the appearance of the fabric and on textures, the influence of the texture on the appearance of the weave. Formation of fabrics by interlacing threads introduce at

right angles is included in the instruction in fabric design, as well as the three foundation weaves, the plain or cotton weave, the production of fancy effects on a plain weave foundation, the various features of twills and satins. All these, and much that is taught beside, enable a student to learn the origin and application of all the simpler weaves used in designing the tion of all the simpler weaves use
various classes of textile fabrics.

Every effort is also made to familiarize the student with the rules and best systems of cloth analysis. He s furnished with samples of every grade of cotton fabrics, and his analyses thereof are thorough.

As a preliminary to carding and spinning instruction, or it may be terme a preliminary course, a study is made of cotton fiber, including botanical classification of cottons. The cotton-producing districts of the world and their products are studied. Commercial grading and classification and the chemical and physical properties of cotton are also considere

Ginning, mixing, the picker room, and carding are taken up in detail, practical instruction therein being given with marke thoroughness. In fly-frame practice proficiency is require in the use of a 32 -spindle slubber with improved differential motion, a 42 -spindle intermediate, 72 and 64 -spindle fine roving frames, 96-spindle jack frame, roving reel, and scale and roving trucks.

It is required of a student in ring spinning that he be thoroughly up in all calculations pertaining to carding and spinning, the grinding and setting of the cards, and the manipulation of white and colore stocks. This knowledge only comes in time, to sure, but it is demanded of a student that during his course he gain the necessary knowledge. Every student must produce a stated amount of warp, filling, and twist yarns. He must also be able to take apart, re-erect, repair and care for 80-spindle, 64-spindle, and 160 pindle combined warp and filling frames, an 80-spindle filling frame, a 360 -spindle $1 \frac{1}{2}$-inch gage spinning mule, and a dozen other of the most modern machines used for twisting, spooling, winding, and reeling. Lectures, recitations, demonstrations, and practice on all the most modern looms constitute the weaving curriculum.

A technical knowledge of yeing is of marke importance to a textile manufacturer. It is, therefore, a fact of interest that in the thoroughly up-to-date technical school, the laboratory and dye house form a feature of note. The object of the course in dyeing is to give the student a clear idea of the fundamental principles which underlie the arts of bleaching and dyeing. This is done by experiment and research, assisted by lectures. Every student is require to properly leach cotton cloth and yarn and to several kinds of textile materials. As a result, he gains expert knowledge concerning artificial coloring matters, compound shades, matching off, testing and valuation of dye stuffs, detection of dyes in the fiber, comparative tests, and the manufacture of dyes.

Besides understanding the different processes of cotton manufacture, a mill superintendent is called upon to manage the motive power, operation, and general economy of an entire plant. This knowledge is gained in the technical school by a thorough course in mechanical engineering, including investigation of the laws of statics, the underlying principles of the varicus general features of machinery, dynamics, strength of materials, the steam engine, power transmission, machine design, mill construction, ventilation, and sanitation. The department of physics in a technical sanitation. The department of physics in a technical
school affords an excellent illustration of the thorough nature of the training. As a rule, physics are not two bear much the same

In the workshop the entire force of knowledge of the student in mechanical engineering is calle into play by his work in the machine shop, smithy, foundry, and woodshop. Throughout the first or apprentice year two days of eight hours each are devote weekly to shop practice. About two-thirds of this time is spent in the woodworking shop. When sufficient skill has been attaine to begin elementary pattern work, the student goes to the foundry, and is given elementary practice in molding. This enales him to understand the conditions imposed by the foundry upon the pattern maker. The remaining three years of a course are generally divided, as regards this class of work, between pattern making, foundry, smith shop, and machine shop. Here the student becomes expert in his understanding, in his practical knowledge, of the work that is always performe in establishments of this

It is apparent that the mission of the technical schools of to-day consists largely of training the rising generation of those who are grouped under the title "captains of industry." They teach not only what the superintendent, the man of affairs in manufacturing work, must know in order to completely discharge his own duties, but they train him as well to look at the applied principle of work from the standpoint of the man at the loom, the forge, the ynamo.

THE LATEST IN CYCLES.

A novel bicycle has been built in London which has been pronounce "as comfortable as a rocking chair" and which shows remarkable mechanical ingenuity. This new machine is fitte with an anti-vibrating easy chair-like sadde which affords wonderful relief to a tired back and which proves a luxury when coasting down long hills. The ladies' machines are meeting with particular favor. They are of exactly the same construction as are the machines built for the men. The illustration gives some idea of the comfort found in these new bicycles.

Besides the chair-like saddle, the machine has another im provement. Note the position of the handle-bars. They are almost directly under the sad. dle. It is this arrangement that enables the woman to ride the diamond frame with ease. The steoring gear is under perfect control and it will be seen that a smaller circle can be describe on this machine than on any ther.

The first machine of this make was built by P. W. Bartlett, of Richmond, England, for a Java resident. He was so pleased that he has now placed an order for twelve more of the same THE LATEST IN CYCLES.

attempted until the student's second year, when his work has fitted him for the solution of the problem that will present themselves. Every modern appliance, or more correctly the most important of these, are utilize in the course of instruction, the Olsen testin machine and the throttling calorimeter being isotable examples. It is an interesting fact that in several technical schools the students have constructed some of the most important of the apparatus in use.

A broa foundation in general and theoretical chemistry is established, so that in future work new problems may be intelligently met and solved. Especial instruction is given in indusirial chemistry. The knowledge he gains here will enable and has enable the graduate student in business life $t_{0}$ determine the relative value of the raw materials oifered by dealers, and to conduct intelligently operations based on chemical principles, detect imperfections in them, and suggest improvements. He is prepare in this way to undertake analytical work of almost any description. So the student gains a practical knowledge of quantitative analysis, consisting of general, applied, and analytical chemistry; inorganic chemistry, qualitative analysis, general methois, applied analytical chem istry; fuel, iron and steel, water, and fertilize analyses; oil testing, organic chemistry, metallurgy, and physical chemistry.

It is plain that the commercial helpfulness of the graduate of a technical school is based on what he can do, rather than on what he knows. Throughout the various courses of a technical school of the first class not an instructor is permitte to either forget th urgency of this principle or to allow his pupils to lack appreciation thereof. So what is known as work shop practice must not ce classe with manual school training, valuable as the latter undoubtedly is. The construction. The weight is somewhat greater than that of the light-weight racing machines, but as these bicycles are built for comfort and not alone for speed this is no detriment. The cost is the same as of any other high-grade bicycle.

\section{THE REMORAS.}

Any one who has spent any time in Southern waters, or engage in shark fishing, is familiar with the re markable fish, remora, shown in the accompanying photograph clinging to the glass by its singular sucker. Nearly all sharks have attendant remoras. I have found them on the swordish, drum, black grouper, and ven upon turtles in the Mexican gulf, and have also caught them when none of these fishes was in the on its dun-colore hide, or against it, will be seen a very distinct black streak parallel with the body about a foot long. Often several will be seen. If at such a time bait is thrown over the lack streak separates itself from its protector and appears as a long, slender, flat-headed fish, the remora, that in a $\mathbf{s}^{\prime}$ nse is parasitic

So strong is the instinct of the remora to sing to the large fish that in most instances it will refuse to leave it when the latter is haule out of the water, clinging with such energy that it can only be to:n away by the display of much strength. I have seen them come ashore on the hammerhead at Santa Catalina, a huge specimen which I captured after several hours, and which only starte inshore when four boats were made fast to it. I have also seen it on the sand shark and the white shark in the Mexican gulf, and doubtless other large fishes are use as a refuge by one or more species. The remora is easily "tamed." I have kept vicinity. When a large shark is seen near the surface, upon the shark. 
several in confinement to experiment with, and legend and psuedo history have played many merry pranks with them. Thus the old Romans called them ship stayers, and several of the classics contain references to them-fishes that fastene themselves to the war galleys and aided in their defeat by holding them back. It will remembere that Pliny, among others, gravely informs us that Antony's ship at Actium was held by a remora, though several hundred sailors rulled at the oars. Then, too, we are told that Caligula's ship was held between Astura and Actium by a remora that was seen clinging to the rudder, pulling hundred stalwart seamen.

The peculiar feature of the remora is the large sucker on the top of its heal that is so conspicuous that an observer who had never seen one would select the belly as the dorsal surface. The fish appears to be tipped upside down; but as stated, the sucker is on the top of the head, and doubtless is a modilication of the first orsal fin, forming a perfect sucker which clings so tightly that have lifte a bucket full of water by allowing the fish to attach itself to the bottom and lifting it by the tail. This sucker resembles a Venetian blind with its cleats, being made up of cartilaginous plates in a double series whose edges are sawlike or serrated. This disk is on the hea and neck and often overhangs the mouth and always the eyes, calling to mind in a very superficial way some of the hornbills among birds. The lower jaw generally projects beyond the upper. The fish is dark, or lead colored, sometimes striped, and presents a singular appearance as it swims about. I once saw a very large man-eater, possibly fifteen feet in length, swimming about my boat, in a deliberate fashion, and as attendants it had six or seven remoras and as many pilot fishes. The atter swam near its head, venturing only a few feet away, while the remoras roame about in every direction, and when I threw pieces of crayfish into the water they rushe at it greedily but were not joined by the pilots.

There are several genera, as Phtheirichthys, Eche neis, Remilevia, Remora, and Rhombochirus. One of the most interesting remoras is Phtheirichthys linealus, as it has two very pronounced white bands running laterally, which give the fish a very striking appearance. In specimens preserved in alcohol or for maldehyde the stripes fade out, but in several which I took from a large hammerhead shark off Avalon Bay, Santa Catalina, the stripes were pure white and the fish a very dark blue black, a most conspicuous object, long, and very slender. I find no record of the fish having been seen on the Pacific coast, Jordan giving its range in the Atlantic north to North Carolina and Pensacola. It is said to attach itself to barraculas in the Atlantic or Gulf of Mexico. I have never notice this, although I have taken y grain and line many at least on the outer reef, is a "isolitary." It lurks in

appears to be a world-wide roamer, carrie hither and yon by large sharks, and common on each side of the continent, and especially in southern seas. It is this remora of which the story is told that fishermen em. ploy it in the Caribbean Sea to catch turtles. The remora is kept, so runs the story, in a pail; a ring is place about its tail and to this a line. When the men sight a turtle the remora is slipped overboard and it is supposed darts at the turtle, seizes it, and holds on with such firmness and vigor that the animal can be hauled in. I lived on the Florida reef, winter and

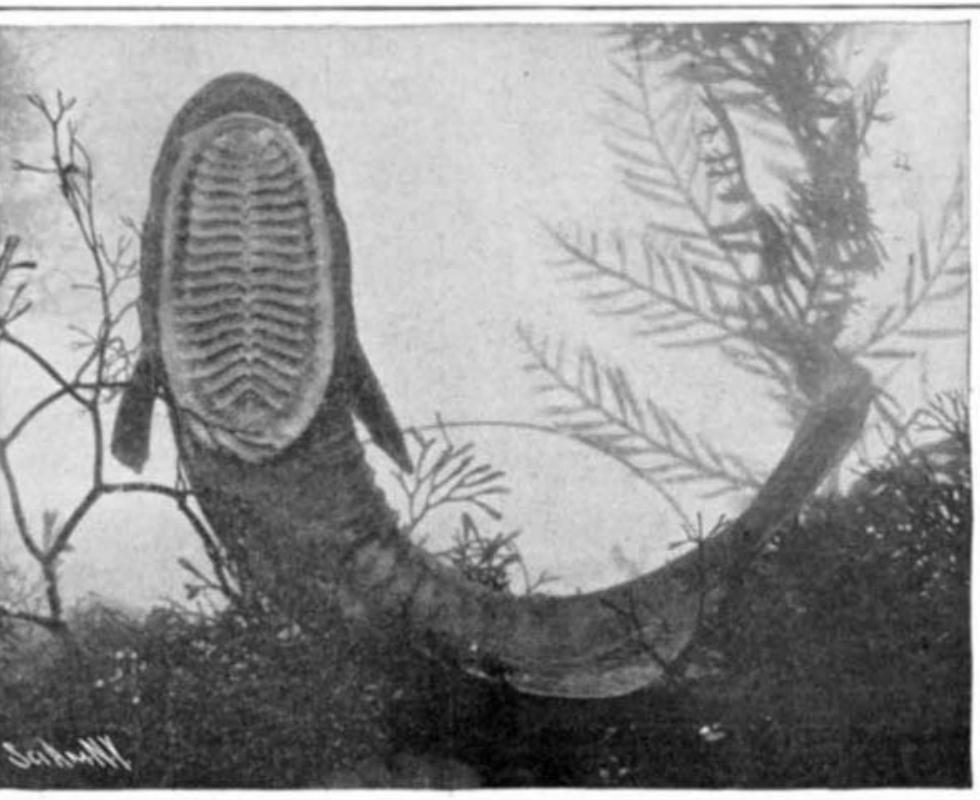

HE REMORA, SHOWING SUCKING DISK WITH SEVENTEEN LAMINE. Taken from large shark at. Santa Catalina Island, Cal.

summer, several years and had a remarkable experience with the various fishes, and among other things I experimented with the remora; but the fish invar ably refused to art after the turtle, preferring to find shelter under the oat. One tosse at a shark was seized by the latter, that doubtless thought it a votive offering. Possibly something was wrong; our remoras may have been stale; they surely were not ship stayers, or turtle. I do not mean to insinuate that this tale is not possible, as so good an authority as Columbu refers to it, and in $1884 \mathrm{Mr}$. Frederick Holmwood, British consul at Zanzibar, described fishing with the remora in that latitude. The fishes, it is said, are kept in a well, and the ring is so firmly place on the tail that it becomes imbeded in the flesh, so that a large turtle can be caught by them.

This remora is found as far north as Gloucester, and Monterey on the Pacific side, and is the common ship stayer of song and story. Two presumable species have been described; one with from twenty-two to twenty-six laminæ, and another with from twenty to twenty-one. A rare and little known remora is Remilegia australis, described by Bennett, and found clinging to a dolphin in tropical water seas. It is a rich
Nantucket and Block Island in the summer, and occa sionally found on the large swordfishes of the latter waters. It is also common on the Florida reef, and said to follow the big sailfish of Cuban waters.

The so-called white remora, Remora albescens, which is not white, rather a gray tint, has thirteen or four teen laminæ in the sucking disk. It is found in the warm waters of the Pacific Ocean, and doubtless strays north in summer, when many large varieties of sharks go north.

A similar remora is include in the genus Rhombo chirus, having been found on the swordfish Tetrapturus on the Atlantic coast ranging from the West Indies north to Cape Cod. A fossil remora is known, described by Cope as - pisthomyzon. It was in general appearance more normal, according to Storms, than the typical remoras of to-day. Its head was not so flat, the jants were equal, the head was narrower, and the sucking disk much smaller than that of the remora of to day. In all probability, the fish was more active, a better swimmer, and not so dependent upon other fishes as are the present forms. upon other fishes as are the present forms.
Very little, if anything, is known of the breeding habits of remoras. In Florida I kept them in dea coral inclosures in order to watch them, but could never find the young.

Few more interesting groups of fishes are known than the remoras, which have figured in legend and history, well known to a few, rarely if ever seen by the majority. The accompanying illustration is a photograph of the fish in the water, taken at Santa Catalina Island, California, under my direction by Charles Ironmonger. It shows the sucker and its partitions perfectly, and doubtless is the only photograph ever taken of the remora, as the fish is rarely caught except when sharks are brought in alive.

\section{THE GREAT SEA WALL AT GALVESTON.}

$$
\text { BT w. S. HUDSON. }
$$

The completion of Galveston's great sea wall marks the first step toward making that city, the most important port on the Gulf coast, storm-proof for all time to come, and also marks the successful culmination of one of the most unique and gigantic engineering under takings in recent years. The building of a solid con crete wall $41 / 2$ miles in length and seventeen feet high and the elevation of the city's grade to the level of the top of the wall is an achievement of which any city twice the size of Galveston might well be proud and when the conditions under which this undertaking was begun are considered, the wonderful nerve of Galvestonians is more properly realized.

Although repeatedy warne to take some measure for the protection of the city from the occasional overflows of the Gulf, it remained for the great disaster of September 8,1900 , to bring the people of Galveston to a complete realization of the necessity for such protection. In the great storm of that date over 8,000 lives were wipe out of existence, more than $\$ 20,000,000$

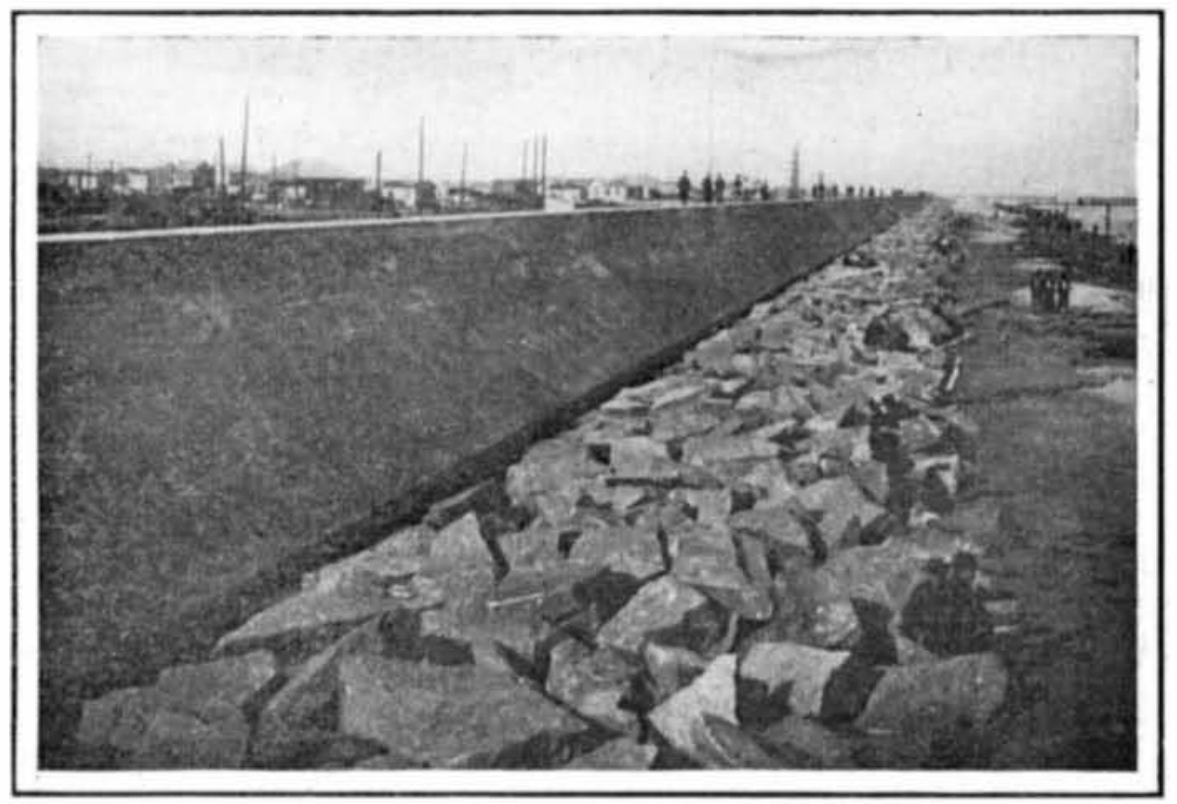

BUILT OF GRANITE AND CEMENT, THE GALVESTON SEA WALL IS 41/2 MILES LONG AND WEIGHS 40,000 POUNDS TO THE FOOT.

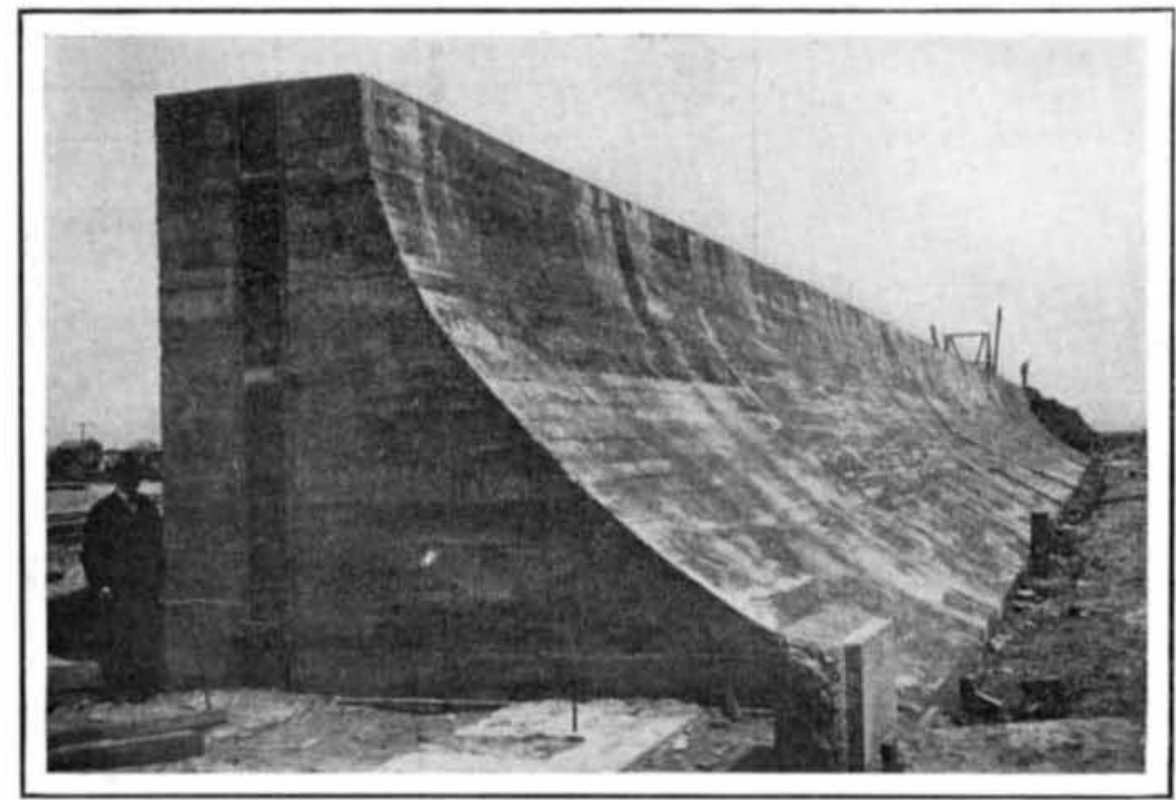

THE GALVESTON WALL MEASURES 16 FEET AT THE BASE, IS 17 FEET HIGH AND 5 FEET ACROSS AT THE TOP. certain places, remaining quiet and poised for long periods, and has a habit, also distasteful to the remora, of swallowing its food entire without crushing it. The remora affects wanderers like the shark, swordfish, and animals which, in their savage rush at prey, crush and macerate it, so that particles escape into the open water, which can be secured.

In Echeneis naucratis the disk is long and has from twenty to twenty-eight laminæ. Its color is brown, with a dark belly, a dark stripe with a white edge extending along the side and through the eye. This brown color and easily distinguished from other remoras by the size of the sucking disk, which is very large and elongate, and has twenty-seven laminæ. The genus Remora is well known, the species of that name being a dark fish about fifteen inches in length, with a large sucking disk, and found on the large sharks that are commonly caught at Santa Catalina in summer, especially the huge monsters that affect the grouper banks in the San Clemente channel. saw four or five of these remoras on one large specimen and the same fish is taken on large sharks at worth of property was destroyed, and faith in the stability of the rapidly-growing city so rudely shaken that five years have not entirely suffice to restore public confidence. When the city had partly recovere from the overwhelming disaster the boar of city commissioners passed a resolution calling for the appointment of a committee to select competent engineers to report upon the following:

1. The safest and most efficient way for protecting he city from overflows of the sea.

2. Plans and specifications and estimates of the cost 